\title{
The Current Situation and Countermeasures Analysis of Cooperation between Private Universities and Enterprises
}

\author{
Shui'e Wang, a , Qingjun Liang ${ }^{2, b}$ and Wenzhun Huang ${ }^{3, c^{*}}$ \\ ${ }^{1}$ Department of Management Engineering, Xijing University, Xi'an 710123, China \\ ${ }^{2}$ Academic affairs office, Xijing University, Xi'an 710123, China \\ ${ }^{3}$ Departments of Electronic Information Engineering, Xijing University, Xi'an 710123, China \\ a1623413621@qq.com, ${ }^{\mathrm{b}} 43329717 @ q q . c o m,{ }^{c}$ huangwenzhun@xijing.edu.cn
}

Keywords: Application; Private colleges; School enterprise cooperation; Countermeasures

\begin{abstract}
In the context of private colleges running to application-oriented universities, in order to full play a role of school enterprise cooperation in training applied technology talents, the author analyses the situation and countermeasures of school enterprise cooperation with the documentation analysis method and case study method, especially between Xijing University and enterprises. It was found that the main problem existed in cooperation between private colleges and enterprises are lower enthusiasm of enterprises and university self-bound on funding sources, concept and faculty. In the end, countermeasures and suggestions are put forward to promote private colleges and enterprises cooperation from aspects on transforming concept, enhancing self-quality, strengthening management, reinforcing training of double-professionally-titled teachers, etc.
\end{abstract}

\section{Introduction}

Up to April 2015, among 408 newly-built universities, there are 140 newly-built private colleges and 268 newly-built public colleges. Newly-built private colleges took $34.31 \%$ of all amounts of newly-built universities [1]. The status of private colleges in the higher education system and the action in the economic society decided training's target for applied talents and running school orientation in service of the regional economic development. Seizing opportunity, moving on, achieving transformed development is needed. Along with our country's industrial structure adjustment and economic development transformation, it should deepen the integration of production and education, also school enterprise cooperation; as well train high-quality and skilled talents; establish a solid foundation for the sustainable development of private colleges.

\section{Status Analysis and Existing Problems}

Status of Cooperation between Private Colleges and Enterprises. At present, see from cooperation field size, tightness and actual effect, many private colleges have established the office of school enterprise cooperation, the cooperation leading group and other similar cooperation leading institutes. Meantime, the private colleges have also formulated the relevant cooperation policies and measures. They are actively proceeding the investigation, communicating with enterprises and constructing the platform of school enterprise cooperation. Many colleges made a cooperation agreement with a large number of enterprises and set up an off-campus practice base. Moreover, based on some professions, the colleges develop order classes and train the talents together with enterprises. As for continuously deepening the cooperation between schools and enterprises, they summarize the experience, put forward the question, better promote to develop deeply school enterprises cooperation, and hold practical seminar. 
Taking Xijing University as an example: Xijing University has established a stable and good relationship with many famous enterprises. They have established cooperation with 367 enterprises and institutions, also set up total 355 off-campus practice and education bases. In 2015, quantities of measures were carried on together. It completely deepened the school enterprise cooperation and vigorously promoted diversified cooperation. The university carried out 22 intramural fairs on school enterprise cooperation. In addition, the university also proceeded on negotiation and cooperation with large enterprises, such as South Korea SamSung group, Shenzhen HUAWEI Co., Ltd., Shenzhen ZTE etc. The university actively promoted construction of resources platform of school enterprise cooperation and built cooperation unit library. There are 12 kinds of forms about school enterprise cooperation as shown in Table 1 .

Table 1 Xijing University, school enterprise cooperation in the form of diversification

\begin{tabular}{|c|l|}
\hline Serial Number & \multicolumn{1}{c|}{ Main Form of Cooperation } \\
\hline 1 & Combined open orientation class, order class and titled class \\
\hline 2 & Co-constructure course \\
\hline 3 & Cooperative develop teaching materials \\
\hline 4 & Joint-setting a project on crosswise issue \\
\hline 5 & Teachers' training in enterprises \\
\hline 6 & Students' practice in enterprises \\
\hline 7 & Holding skills competition collaborated with enterprises \\
\hline 8 & Executives' teaching \\
\hline 9 & Organizing forum on school enterprise cooperation \\
\hline 10 & Building up a laboratory together \\
\hline 11 & Executives participating in the university's personnel training program revision \\
\hline 12 & Absorbing enterprises into the university \\
\hline
\end{tabular}

The Main Problems Existing in School Enterprise Cooperation. Although school enterprise cooperation has achieved certain success, the university got much more enthusiasm than enterprise. Most of them signed agreement with vigour, but got anticlimax in implementation. There is a series of fundamental difficulties in school enterprise cooperation. Mainly reflect in:

- Lower enthusiasm of enterprises

The mode of cooperation between colleges and enterprises mainly is dominated by universities, oriented by enterprise and lead by government. Presently our cooperation mode is basically dominated by university, and limited think of enterprises' demands. The ultimate goal of enterprises is to make profit. Thus, cooperating with enterprise, it is necessary to guarantee enterprise' economic benefit. But actually, enterprises, especially the well-known enterprises are unwilling to cooperate with private colleges. It is mainly caused by the following five reasons: First, the advantage of university is intelligence and technical support by both teachers and students. However, this is precisely weakness of the private colleges. Private colleges are not strong in scientific research and technical power. Therefore, if enterprises need deeply develop cooperation and train staffs, they are usually priority to choose well-known public universities. On the other hand, because students' skill level is lower, it is difficult to reach the requirements of internship. Second, based on enterprises' need on protection of business secrets, they do not allow students to contact the core or the main business. Third, cooperation projects of students' practice, training and others will increase operating costs of enterprise. Forth, enterprises need arrange guidance teachers, which make human resources more nervous. Fifth, increase enterprises' unexpected risks and management difficulty [2].

Based on the above, most of enterprises cooperated with universities are medium and small ones. Nevertheless, both sides cooperation way limits in university providing cheap labour to enterprises, or 
only selling or disguised selling products and hardware, such as teaching instruments and equipments, teaching software, etc., or stopping in a line operational work [3]. Eventually, it makes three parties of students, school and enterprises unsatisfied. It cannot realize the begin purpose of school enterprises cooperation.

- Colleges self-bound

The funds source of private universities determines its enterprise characteristics. Private colleges take investment on running a school as the subject. Its operation costs highly depend on the tuition fees. Wu Daguang's research shows that almost $80 \%$ of private colleges in our country are investing in running schools [4]. Since it is an investment in running schools, the founders would like to receive a return. Therefore, in the process of running a school, it is very serious that demand of quantity is much over than the quality. The status of excessive pursuit of economic efficiency directly result in difficulty to carry out a deep level of school enterprise cooperation. So that, it ignored the quality of personnel training and trend of market demand.

Private colleges education service attribute determines the dual motivation about the private colleges in the development orientation and characteristics of formed surrounding and sustaining to cultivate qualified talents and getting a reasonable return. It implements the low cost and high efficiency, both control on quality and cost, which affects private colleges talent training specifications, structure, service oriented and the allocation of resources [5].

Refer to managers of private colleges, mostly are from public universities, or long-term receiving ideological edification by public universities, especially the research university. They did not have a clear understanding of Applied Technology University. For the cultivation of students, they focused on theory, but ignored practice. Thus, schools and enterprises cooperation stay in the level of solving practice or employment. The specific performance of the following five points: First, they concentrate on teaching and the number of papers published, but not on the school enterprise cooperation. They think the school enterprise cooperation is an emergency and short-term behaviour [2]. Second, the signed cooperation agreement is macroscopic and general. There are no authority guidelines and rules of the school enterprise cooperation.Third, the majority of colleges pay more attention to school enterprise cooperation in the short-term and establish the school enterprise cooperation office and other institutions. However, from the long running, its role play is not sufficient. Forth, the feedback mechanism is not perfect. During the course of the school enterprise cooperation, it is lack of overall planning. Or, in order to cooperate, then cooperate. Paying more attention on form than content caused the lack of communication among the school, the student and the cooperative enterprise, the lack of timely information feedback. Of course, it cannot better meet the needs of all parties. Ultimately it makes the school enterprise cooperation become formalistic [6]. Fifth, safety is the lifeline of the private school. Due to the survival and development of private schools is in the cracks of survival, as well society prejudice for private schools etc., the private colleges must put safety in the first place during the development. Mentioned security risks in school enterprise cooperation, students personal safety, property safety, information security (cooperated enterprise personnel and commercial secret security, enterprise technical data leakage, students personal information being used, etc.), culture safety (enterprises' strict work rules and college students' free activity, profits first for enterprises and people-oriented for college students) etc. All of that make more safety risks between the school enterprise cooperation and both parties need take great responsibilities [7].

- The problem of faculty in Private Colleges

Application of technical undergraduate education is to highlight the practice, strengthen the application of the characteristics of education. Therefore, it is necessary to pay attention to ability training, but also should pay attention to the basic theory teaching, so as to cultivate profound theoretical basis, practical ability, good skilled use of theoretical knowledge and flexible to solve the problem of applied talents. Thus, it requests that teachers must be "double-professionally-titled teachers ". That is: teachers should not only possess the quality of theoretical teaching, but also have 
the quality of practical teaching. But in fact, because of higher threshold of the teachers' education level, general private undergraduate requirements are for master's degree and above, it made the teacher is academic talent as "from the gate into the gate". Teachers' theoretical knowledge is rich and solid, but lack of practical experience. On the other hand, the threshold of education has hindered the pace of absorbing teachers from enterprises. No matter quantity, quality or structure, there is a big gap of faculty between private colleges and public universities.

At present, due to the tension of college faculty, esp. more of private colleges, teachers' teaching is more adequate. But for off campus students practice, school selected teachers to guide practice, meantime complete teaching tasks, which have strict evaluation mechanism, after weighing, teachers take to cope with practice with random indication. Therefore, the private colleges should carry out the relevant rules to ensure that teachers have sufficient guidance time.

\section{School Enterprise Cooperation Strategy Analysis for Private Colleges}

Mobilize the Enthusiasm of Enterprises. As the subject of market management, enterprises' basic goal is to make profit. Whether universities and enterprises can maintain long-term cooperative relationship, it was based on whether the cooperation can bring good social benefits and economic benefits.

First of all, it must change the idea of profit being the supreme. It must establish a long-term vision, strategic vision and sense of responsibility. That is the key to consolidate the cooperation well. Enterprises and private institutions develop cooperative education, which is not a taste of free pay, but the most effective way of investment for the future development of the enterprise itself. Through supporting education, it reach publicity efficiency, so as to establish a corporate image, meanwhile, advance educate the future potential customers, enhance the competitiveness of enterprises and products. Moreover, participating in colleges personnel training is entrepreneurs' inescapable responsibility to society.

Secondly, private colleges must strengthen their own quality, deepen the cooperation between enterprise according to enterprises' requirements. The high quality resources of teachers and students of colleges is the most important thing that enterprise value. So, private colleges must improve their own scientific research ability, especially for orientation to applied running. It must lead students and teachers to research and create some utility model patent and invention, or combined with the fact, develop. Both meet the enterprise's actual demand and increase the chips in the school enterprise cooperation. For example, Xijing University obtain 7 patents and 113 utility model inventions granted in 2015; sign 20 contracts on horizontal issues; institution of mechanical engineering and Shaanxi Automobile Group cooperation, joint research and development of heavy-duty truck's dashboard has been put into mass production; institution of control engineering actively carry out LED R \& D, production and sales.

Finally, give full play to the role of policy guidance and protection. The specific policies and measures to promote the cooperation between colleges and enterprises, the current situation of the lower cooperating power and the weak sense of responsibility of enterprises, it need carry out the "Regulations" in soonest, provide policy and legal protection; Make clear preferential tax policy for involved in school enterprise cooperation enterprises; Try for other projects of enterprise income tax preferential and business tax, value-added tax etc. preferential; Also in a variety of selection activities, put the school enterprise cooperation into the performance appraisal index system; Establish the typical model of school enterprise cooperation. Provincial and municipal level must carry out regulations and measures which are appropriate for local characteristics.

Change Universities' Concept and Strengthen Management. First of all, the concept of private colleges need to be changed earlier. Upon the cooperation of schools and enterprises, achieve the seamless connection of personnel training. All colleges give full play to the function of social service. 
Down to earth is the survival and development way for local colleges and universities. To lead the school closely around "local and application" running orientation, strengthen the applied discipline and specialty construction, all need to use the school enterprise cooperation. By the way of superposition advantage, open and build together, sharing laboratory and practice base. Through the cooperation between school and enterprise, absorb vocational qualification standards, industry standards, enterprise core technical standards, industry experts; guide enterprises to actively participate in the work of talents cultivation; establish school enterprise cooperation "dual system" [8]; make realization of seamless connection of talent cultivation; with very strong practical ability of student resource, mobilize enterprises' initiative to participate in school enterprise cooperation. For example, the first half of 2015, Xijing University news media department sent more than 10 outstanding students to participate in the project to build together among the Department and the Shaanxi media network and the first life. Each student entered the enterprise was allocated in separate job to complete the media editing program. In the summer of 2015, signed a joint production of competitive workplace reality show "super intern agreement" with the network. The Department was responsible for copy planning, shooting and post - editing, network was responsible for technical guidance, and coordination with the enterprise, also packaging and promotion.

Secondly, it is also very important to scientific management of private colleges. One is to increase investment in school enterprise cooperation and improve the system protection. Private colleges should continue to increase the necessary funds for school enterprise cooperation, to meet the teaching needs of students and teachers in the school enterprise cooperation. Establish and improve rules of investment and using management of school enterprise cooperation's funding; rise up the efficiency of the funds use. Private colleges should improve various systems of the school enterprise cooperation. Speak as Xijing university, it carried out a series of "the Xijing university's school enterprise cooperation 13-5 planning ", "the Xijing university secondary Department of the school enterprise cooperation term evaluation index system", "the Xijing university school enterprise cooperation oriented class teaching management interim measures", "the Xijing university off-campus practice base construction and management measures", "the Xijing university school enterprise cooperation credits replacement management measures" etc. The other is to strengthen the scientific management of the whole process of school enterprise cooperation from selecting cooperated enterprise, signing agreement, project implementation, project supervision, project end, project evaluation, performance evaluation, data archiving etc. Get the efficiency of management and the benefit of the school enterprise cooperation. Make the school enterprise cooperation deepening and consolidating. And increase the inspection and appraisal work of school enterprise cooperation; timely carding school enterprise cooperation agreement and real-time tracking order class construction work mechanism; promote the mechanism formation of school enterprise cooperation units exit, so that ensure the effective implementation of school enterprise cooperation. The third is to establish information feedback system. In order to safeguard the effect on school enterprise cooperation, it should establish the true information feedback mechanism, including students' feedback in the cooperation on the training content and effect, enterprises' feedback for students practice. University have to provide timely and true feedback on students' internship [9]. Only in this way, we can find and solve the problems in time, so as to ensure the cooperation goal between two sides to be reality, to ensure long-term and efficient development of school enterprise cooperation.

Finally, based on the cooperation between school and enterprise, strengthen the training of double-professional-titled teachers. Private colleges should get plans to send young teachers to full-time work practice and short-term learning and training in cooperated enterprise according to professional construction and personnel training needs. Teachers are calculated in accordance with the corresponding workload during the practice period. University should leave enough time for teachers to learning and training in the enterprise when teaching assignments; give full play to the advantages of university teachers' scientific research; support teachers together with enterprise to report projects of 
production and technology application; give rewards to the host who can put the research achievements and technology used in the production, even by extension or converting to form products, in accordance with the relevant provisions of the Research Award; refer to assessment of teachers, it should be appropriate with the characteristics of teaching and application of private undergraduate, and correspondingly reduce the requirements of scientific research; vigorously absorb teachers with plenty of practical experience, such as that the Xijing University give policy tilt to double-professional-titled teachers when talent absorbing; encourage teachers to practice in enterprise; for double qualified teachers identified, there is strict requirement that have experience of practice in enterprise. Once identified as double qualified teachers, monthly salary increase 500 - 1000 yuan.

\section{Conclusion and Summary}

In this paper, we conduct research on the status and countermeasures analysis of cooperation between private colleges and enterprises taking Xijing University and enterprises' cooperation as an example. School enterprise cooperation is benefit for private colleges to improve major setup, talents training mode, curriculum reform, teaching material construction, practice training and employment, cooperation of production, study and research, double qualified teacher training, shorten the training cycle, reduce personnel training cost [10], etc. School enterprise cooperation had important realized significance to promote the health development of private college. School enterprise cooperation is of far-reaching significance. However, there still exist some problems, such as the formation of long-term mechanism of college enterprise cooperation, the formulation of scientific evaluation system, the establishment of incentive policy, etc. There are still large development spaces of school enterprise cooperation, which need us to actively explore.

\section{Acknowledgements}

This research was financially supported by the 2015 Research Project of Higher Education Reform in Shaanxi (15BY126) and the 2015 Teaching Reform Research Planning Project of Xijing University (JGGH1511).

\section{References}

[1] Y. A. Gu: The newly built undergraduate colleges and universities transformation cannot be "one size fits all", China Education newspaper, (2015.6.18), p.001.

[2] J. Jin and F. Zhao: Brand (Second half of a month), (2014) No.9, p.141.

[3] K. M. Zhi: Shaanxi Education (Higher Education Edition), (2013) No.z1, p.66.

[4] D. G. Wu: Educational research, (2007) No.1, p.3.

[5] Y. X. Ke: Universities (Academic Edition), (2013) No.4, p.84.

[6] D. F. Pan: The industry observation, (2015) No.3, p.144.

[7] D. D. Tong, Y. D. Cui and C. Y. Tong: Management, (2012) No.23, p.17.

[8] H. P. Li: Looking for "Nereus needle" in the transformation of local colleges and universities [EB / OL]. http://edu.people.com.cn/n/2015/1123/c1053-27844282.html, (2015-11-23).

[9] J. H. Lang: Occupation education, (2015) No.10, p.254.

[10] D. Zhou: Journal of Huanghe Science and Technology College, (2012) No.4, p.17. 